\title{
Challenges in Teaching English in Mixed Ability Classrooms
}

\author{
Bhim Lal Bhandari*
}

\begin{abstract}
The purpose of this study is to explore challenges in teaching English in large mixed ability classrooms. The study was framed under qualitative research design. In order to collect data, semi-structured interviews and open -ended questions were asked to four English language teachers teaching in secondary level. The study explores since the textbook does not address the needs of a diverse class population; students lose their interest. Almost all the participants reported that problem of discipline, difficulty of correcting errors in written assignment, problem of addressing multiple intelligences and interests, individual attention, difficulty in managing teaching materials, lack of equal participants of learners were the major challenges of mixed ability class.
\end{abstract}

Key Words: Classroom management, homogeneous class, mixed ability class, multiple intelligence, professional development

\section{Introduction}

Mixed ability class is one that has learners of different language learning abilities, pace, language knowledge and linguistic background, learning style and experience. In this regard, Ur (2009) states that mix-ability class is one that has different kinds of learners of different intelligence, experience and learning style in it. Such a class is challenging and complicated for less experienced teachers due to learners' different proficiency, knowledge, intelligence, linguistic and socio-cultural background, learning styles and poor physical facilities of the class. Mixed ability classroom teaching is one of the most challenging tasks though it has some opportunities. The teacher with poor professional competency and skill cannot adapt all kinds of teaching learning activities to suit to strong, average and below average learners "Mixed-ability classes are those where students differ greatly in ability, motivation for learning English, needs, interests, educational background, styles of learning, anxiety, experiences and so on" (Ainslie, 1994). In mixed ability classes, students work together with teachers in spite of the differences in individual skills, personal interests, personalities and learning needs. Due to great variation in these abilities, it is difficult to address the appropriate teaching styles to correspond to the students' capabilities and learning styles.

Many teachers are extremely worried about the fact that they have the students in their classes who are at different levels of proficiency. Indeed, mixed ability classes are major preoccupation for most of us because they appear to make planning and the execution of plans in lessons extremely different (Harmer, 2009). In fact, almost all the students of school level are divided into different abilities. It seems nearly impossible to have the learners of homogeneous in a language class in all aspects. Teaching English is not out of challenges. Every teacher must be familiar with the varied needs of their students so that they can

*Associate Professor, Department of English Education, Butwal Multiple Campus, Butwal 
provide a number of suitable teaching ideas. Richards (1998, p.1) asserts that "every class we ever teach is mixed ability". Every learner has his/her own learning style and linguistic background knowledge.

In Nepalese context, while teaching English, language teachers have been facing many problems and challenges. One of the greatest challenges they face is heterogeneous class where students are of different language learning abilities, pace, language knowledge and linguistic background, learning style and experiences. Some are competent, quick, confident, and independent whereas others are average, poor, slow, dependent and shy. Some love working independently whereas others love learning through interaction. Such classes are usually problematic since the learners having different intelligence, socio-cultural background, and interests learn language together. It is difficult for both teacher and students to make interaction and contact with students of the back benches. Similarly, it is difficult for students to ask and receive individual attention as well.

\section{My Endeavor with Mixed Ability Classes}

I started my teaching career as an English language teacher from a community school in a rural municipality in Western part of Nepal. I encountered with mixed ability learners having different intelligence, socio-cultural background, interests and linguistic background. In the beginning, I found such classes more challenging and problematic. However, slowly and gradually I was familiar with the learners of diverse backgrounds and levels and types of intelligence, I found out the ways of transferring the pressure of mixed ability scenario into relaxing environment. I promoted collaborative environment in the class without imposing the ideas by developing good atmosphere. The learners can share their new knowledge and life experiences, more varied opinions, interests and ideas to each other frequently to increase their own knowledge and awareness of others. Despite the fact that the mixed ability class is of great challenge, it provides interesting learning environment, promotes, and enhances teaching and learning opportunities activities and make learners creative and innovative. In this context, my research attempts to explore challenges in teaching English in large mixed ability classrooms with diverse learners.

\section{Statement of the Problem}

The problem being addressed in this study is to explore the challenges in teaching English language in mixed-ability classrooms and provide solutions to handle these problems. Majority of teachers are still depending on traditional ways of teaching rather modern ones. Here, traditional methods of teaching mean the use of grammar translation, audio-lingual and lecture methods where students get very little time for speaking practice and feedback. They do not implement theoretical knowledge in real teaching. All the teachers are not equally competent and proficient in their profession as they do not have equal theoretical and practical knowledge. Taking this general assumption of individual differences in implementing theoretical knowledge of their training in real teaching into consideration, the researcher is trying to explore the challenges encountered by English teachers in mixed-ability classrooms. Due to lack of required skills and teaching methods to deal with mixed-ability classes, learners are unable to give equal learning opportunities to all the students in the class. In this regard, Baker (2002) states that the task can be introduced by use of different methods so that students' abilities can be addressed. The difficulties faced by language teachers in mixed-ability classes lead to frustrations on their part in teaching. They are unable to create a productive learning and teaching environment in the class. The students with a highability get bored as the teacher tries to make further explanations to the students with average ability to low levels of knowledge. Address the needs of every student in the class is a challenging job. Therefore, serious attention needs to be given in order to address 
learner differences and bring changes in teachers and learners in diverse contexts.

The study is significant because it will explore the challenges and throw light on handling mixed ability class in Rupandehi. There are many factors which hinder to implement the teaching skills in the classroom. The study stimulates to language teachers and instructors who are associated with the teaching field for their further research and professional development. In this context, Brown (2002) stresses the significance of assessing students in identifying their learning strategies to establish to develop better study skills that work best for them. The significance of this study cannot be under estimated. Instead, it is beneficial for the students, teachers and researchers who are conducting research in this area. The research is also expected to be significant and helpful for teachers, training institutions, trainers, training curriculum designer, schools, school administrations, school management and student teachers also. The findings of this work will suggest some pedagogical implications in the field of teaching and learning. The study will be a milestone to provide a base for future researchers in this field since there are no any specific studies on it, the study is expected to be useful as a reference material. This research work is equally significant for those who want to study further in this field in future.

The purpose of the study was to explore challenges in teaching English in mixed ability classrooms. The study addresses the following research questions:

1. What are the challenges in teaching English in large mixed ability classrooms?

2. How can teachers overcome the challenges?

\section{Literature Review}

In mixed-ability classes, there are students with varying capacities, motivation for learning, experiences, interests, learning needs, learning styles, Language, cultural background among other characteristics (Baker, 2002). It is significant to differentiate between the mixed ability classes and teaching so that the teachers can provide work for mixed ability teaching styles.

Regardless of the place or the type of school, the existences of mixed ability classes are inevitable. Each individual has unique characteristics and need which are very different from the rest of the students in several aspects (Ireson \& Hallam, 2001). Gender, attitudes, intelligence, confidence, motivation, language development, ethnicity, age and culture play a very big role in determining the learning preferences of each student. However, this may fail when the teacher insists on teaching the students as a group of homogenous individuals or average students. It would be unrealistic to expect that students with different capabilities to learn through the lesson and curriculum at the same pace (Susan \& Judith, 2005, p. 5).

Harmer (2008) points out, "Teachers of English along with teachers of other curriculum subjects regularly face mixed ability groups where different individuals are at different levels and have different ability tasks". Now-a-days, most of the language course books provide support with mixed level learning with multilevel task sheers. In such a case, all kinds of learners can have plenty of opportunities to learn many things without obvious effort in real. In this regard, Richards and Renandya (2010) write, "With a long complex text, a simple task makes the reading or listening achievable for weaker students with a shorter, simple text the task can be more demanding." The teacher who has the idea of using simple task with a long complex text, providing different notes teaching learning will be successful and achievable.

Although mixed/heterogeneous classes are most of the time seen as problematical ones, they also have their benefits. Ur (2005) states that some of them can also be used to solve problems students' knowledge, varied opinion; interests and ideas can be used in classroom interaction. Students increase their knowledge and awareness of others in heterogeneous classes; there is much more peer-teaching and collaboration among students since teachers are less able to attend every individual student; classes are 
more challenging and interesting for teachers and students.

Despite the problems of heterogeneous class, there are a number of benefits. Hess (2001) points out:

In such classes there are always enough students to get interaction going, and there is a rich variety of human resources. Furthermore, there are many possible teachers in the class, and as she says, we will never get bored because the challenge is great.

There are always enough students to get interaction. So, such classes can provide a much richer pool of human resources than do smaller or less mixed classes. The learners can share their new knowledge and life experience, more varied opinions, more interests and ideas each other frequently. It is the only way to motivate learning. When students come in contact with their friends, they get to know other's values personalities, cultures etc. which help them increase their own knowledge and awareness of others. Hence they come to know many things easily. Since the teacher in unable to pay individual attention in the class, the students can develop the habit of learning from each other working together in peer teaching and collaboration. Such classes are more challenging and interesting to teach and provide greater opportunity for creativity, innovation and general professional development.

Promoting collaborative learning environment in the language class is the best way in dealing with mixed ability learners. They can also be referred to as a variation of students in their abilities in grammatical knowledge, fluency and accuracy, size of vocabulary, receptive and productive skills (Valentic, 2005). Ansari (2013) for instance describes a mixed-ability class as comprising of not only learners with various capacities but also those that have a broad range of preferences and learning styles. Notably, there are many factors which may differ from one student to another such as their attitude, motivation, and self-discipline (Lightbown \& Spada, 2006). This makes it difficult for the teachers to effectively plan form their lessons to ensure that all their students reap the required benefits from the lesson.

However, there are advantages associated with teaching in mixed-ability classes. These classes provide interesting learning environments because they are composed of a rich pool of diverse skills, dispositions and perspectives. Most importantly, the interactions in these classes enable the students to be more creative and innovative as they learn from each other's unique abilities. However, the difficulties faced by language teachers in mixed-ability classes are innumerable which lead to frustrations on their part since they are unable to create a productive learning and teaching environment for their students. Teachers in mixedability classrooms need to be afforded continuous training to better manage the challenges of their diverse learners (Butterworth, 2010). Most classes are comprised of a large number of students, and it is the responsibility of the teacher to control the students and to deliver the lesson effectively. The students with a high-ability of understanding get bored as the instructor tries to make further explanations to the students with moderate to low levels of knowledge absorbing capabilities. The most challenging part of English language teaching in a mixed-ability class is the fact that the teachers are expected to guide students at their individual pace, regardless of the proficiency differences. Failure by the teacher to address the needs of every student often makes the active students maintain their active state whilst their more passive counterparts remain passive, with no positive development (Hedge, 2008).

Nusrat (2017) examined overcoming the challenges faced in a mixed ability classroom in Dhaka, Bangladesh. This study reveals language teachers simply cannot avoid a mixed ability classroom. It is practically impossible to get a homogeneous classroom as no ability grouping is absolute. It is better to accept the reality and apply certain strategies to ensure 
effective learning for all. To overcome the challenges of mixed ability classroom, the teachers need to design the course contents in such a way that allow scopes for optimum learning for both higher and lower ability students and choose a wide range of classroom activities that interest and motivate every learner. They also closely monitor every student to assess their gradual progression and ensure that everyone is utilizing their full potential for effective learning of every learner.

\section{Methodology}

The study was based on a qualitative research method to explore challenges in teaching English in large mixed ability classrooms and explore the strategies used by them to handle the problems. I selected 4 secondary level English language teachers teaching in mixed ability classes from 4 community secondary schools of Rupandehi district. I collected the data through semi- structured interview and open-ended questions from the participants using purposive sampling procedure. The purpose of the questions was to find out the problems which teachers have faced in mixed ability classes. The collected data were coded and categorized under different themes through qualitative techniques. These codes were organized around research questions. To maintain ethical considerations and anonymity, the identities of the participants were masked using pseudonyms and the data were analyzed and interpreted descriptively.

\section{Delimitations of the Study}

The prime concern of the study was to explore challenges in teaching English in large mixed ability classrooms and to explore the strategies used by teachers to handle these challenges faced by English language teachers and some ways to handle these problems. It was limited to secondary school level English language teachers of Rupandehi district. The study consisted of small sample size i.e. four English teachers who were selected purposively. Open-ended questions and semi structured interviews were adopted as the research techniques for data collection.

\section{Results \& Discussions}

There are many challenges while dealing with mixed-ability students in the class due to the students' different backgrounds. It is also important to vary the materials to get the students interested in learning. Every teacher faces a number of problems while teaching to students of different levels of ability. The teacher meets these mixed-ability classes each day. Baker (2002) argues that:

It is not just the fact that there are many students in a class, but that all of them are at so many different ability levels that provide the biggest challenge. She further claims that in mixed-ability classes it can be difficult to keep the attention of all students. Their motivation can be poor and the teacher can feel frustrated because he/she does not have enough time to help the weaker students. Many teachers working with mixed ability class may face difficulties and problems in teaching career. In such a class, teaching is more challenging and complicated for them. A mixed-ability class can seem uncooperative, the students can get bored easily and this can cause commotion in the classroom. Planning the lesson and making work-material can take too much time for the teacher and the planned material is often too easy or too difficult for the students. This may make the teacher feel inadequate and unable to cope with the class (Hess, 2001).

ELT programme in Nepal cannot achieve the recognized standard in higher education as long as mixed ability classes in institutional and community schools along with campuses are managed properly only then various complicated existing problems can be minimized. Mixed ability class present some problems: Proficiency and ability vary widely among students; individual teacher-student attention is minimized; student's opportunities to speak are lessened and teacher feedback on students' written work is limited (Brown, 2007). The teacher also has to encourage everyone and give positive feedback, and 
give them advice on what they need to practice more. Thematic analysis of questions and interview in mixed ability class are as follows:

\section{Problem of discipline}

Usually discipline is an inevitable requirement of teaching learning. If it is not managed properly, it creates a great trouble for the teacher to handle the class smoothly and efficiently when students do not co-operate him/her. In this context, teacher -3 said:

I have serious discipline problem in the multilevel class. In my class, fast finishers carry out their tasks before their classmates. In this context, weak learners either lose their confidence or disrupt others as they cannot respond my questions as quickly as their counterparts. Problems arise when they do not understand.

This reveals that discipline is one of the challenges of mixed ability class. It is difficult to teach the students if they are out of control. If the tasks and materials of the lesson are not interesting, discipline problems can occur and they are also associated with boredom.

\section{Correcting written assignments}

Majority of the teachers reported that they have difficulty in correcting students' writing tasks in time. In such a situation, they may develop the habit of writing incorrectly. Teacher-1 said,

I cannot correct my students' assignment in time, however, I usually develop a personal relationship with the students, encourage them and give them positive feedback and correct all their mistakes and talk to them about what they need to work more with.

Correcting errors on various tasks in written assignments is very significant to scaffold learning especially for the weak learners but teachers can't. The teachers has to develop a personal relationship with the students, encourage them and give them positive feedback and correct all their mistakes and talk to them about what they need to work more with

\section{Problem of addressing multiple intelligences}

Majority of the teachers reported that there are the students of different interests and multiple intelligences and abilities having different cultural and academic back ground. All of them my not be interested in the topics and activities provided by the teacher. He or she has to develop easier version of the same home work for the weaker learners. The class may be homogeneous only in few aspects but it will be heterogeneous in many aspects. In such a class, teaching is more challenging, problematic and complicated as students are of different abilities and language levels, different intelligences, different learning speeds and different learning styles and preferences.

In this regard, teacher -1 said, "In my class, there are different kinds of learners. Some of them learn by listening, some learn by seeing whereas others by doing. But I usually cannot address their multiple intelligences" This reveals the fact that, it is difficult to organize creative and dynamic teaching without addressing learners' multiple intelligences. Bright, average and poor learners can't work together full interaction between teachers and students in class is very low. It is thus, obvious that we cannot expect a dramatic change in students. If this is the case, it will be just waste of time, money, energy in terms of resources and manpower utilized to produce under qualified graduates whose skills are not marketable in the highly competitive job market of modern era. This idea of participant coincides with the idea of (Ireson \& Hallam, 2001) who asserts each individual has unique characteristics and need which are very different from the rest of the students in several aspects.

\section{Less effective learning}

Effective learning depends on effective teaching. Due to lack of effective communication and application of teaching aids, teacher can't make sure that the students are all learning effectively. Regarding this issue, teacher 4 said, "The tasks that I provide are either too difficult or too easy for many of my learners 
as a result effective learning for all seems to be impossible". In such a class, individual attention is challenging because of varied level of competency, proficiency, as well as the mixture abilities and language levels of learners.

\section{Lack of effective and careful planning and preparation}

Teaching is not an essay job, just delivering lecture in front of the class is not everything but it is a challenging job. In this regard, participant 2 said, "I usually teach my students without systematic and careful planning; though I know planning assists the teacher in teaching heterogeneous class". It is difficult for teacher to make the class interactive and lively without effective and careful planning. The work of lesson planning for every learner as determined by the different learning abilities and styles is quite challenging. The teaching styles have to correspond to the students' capacities and learning styles otherwise, the teacher will go out of track. However, most teachers were found not balancing theory and practice in classes. They often have a great variation in these activities.

\section{Lack of well management of the class}

Well management is vital to create the condition for successful learning. It is the process of ensuring the lessons run smoothly to optimize academic engagement of students. It is the process of setting up all the activities to promote student learning successful. Regarding the challenges they face while teaching in large mixed ability class, participant 4 explained, "My classrooms are not with well ventilation, sufficient furniture, neat and clean white board, hearing system, and disciplined students etc to provide a favourable atmosphere to everyone". In order to handle the class successfully and effectively, the teachers must have clear vision, commitment, devotion, dedication, well preparation, well management skill and professionalism towards his/her teaching.

\section{Inefficiency in managing teaching materials}

Proper and sufficient management of materials attract the attention of the students and facilitate better language learning. However, it was found that the teachers could not find suitable materials for the learners. Regarding my query related to the challenges that teachers are facing while teaching in mix-ability class participant 2 responded,

I cannot manage teaching materials properly in my class so; it is quite difficult to me to handle the mixed ability classes effectively. I frequently face this problem and class seems to be a bit unmanageable, indiscipline and boring. Also, I cannot conduct the teaching activities as smoothly as I desire. Almost all the text books that I am using are homogeneous which aim at one particular kind of learners. Moreover, there is no option or flexibility of materials.

The expression of the participant 1 showed that it is the teacher's duty to consider the appropriacy of teaching materials for the EFL mixed ability class. Appropriate use of teaching materials can facilitate learning. However, mot materials are designed for average learners and homogeneous classes. The teacher must have the idea on using and operating them easily. Teachers are unable to manage suitable teaching materials to encourage the learners learn equally.

\section{Balancing voice and body language}

The volume of their speech and the body language that they use while teaching play very important role to motivate the learners in the class. Regarding balancing voice and body language, teache2 claimed, "My voice is normal and audible enough and I try to use verbal language along with the body language". Most of the information can be made easier, comprehensible and effective to all kinds of learners. To make teaching effective for all, verbal forms need to be incorporated with body language.

\section{Poor involvement of students}

When teacher uses all the activities according to students' level, need, and interest, students' participation will be high. Until and unless teacher gets to know and follow the progress of all the 
individuals in the class, they neglect their studies. Regarding the question related to challenges on poor involvement of students, participant Teacher -4 said, "There are many students in my class and every individual is different from each other in their learning. Those who are less proficient can't take charge of their learning". The expression of participant 4 showed that due to individual differences, teacher can't activate them all as they need to be Those who are more proficient and confident are ready to respond his questions whereas; others remain silent throughout the class. Since one teaching style does not fit for all, the teacher cannot address all. Communicative activities provide equal opportunities to all the students. Similarly, participant 3 regarding the same question stated, "I try to engage my learners in learning activities to make them learn better, however, poor learners are not involved in learning activities. Their low participation in various activities of the class hinders them to achieve the desired goal".

This response mainly highlights the problem of poor involvement of students. Without equal participation of the learners in the classroom activities, no one can expect fruitful and effective output in mixed ability class. The teacher, who is well experienced in teaching, can provide sufficient opportunities to the learners to learn language effectively. In this context, Butterworth (2010) suggests that teachers in mixedability classrooms need to be afforded continuous training to better manage the challenges of their diverse learners.

\section{Use of different pace for different activities}

In heterogeneous class, some learners can catch either pace i.e. fast or slow easily whereas others cannot. Very fast speed of the speech will be useless to poor students and slow speed will also be monotonous to the bright ones. When teachers vary the pace for different activities, it will be fit for all. Majority of the teachers involved in the study reported that they could not use different pace for different activities. In this regard, teacher-4 said:

As a teacher, I know I need to go slowly and I should not continue my teaching until everybody understands. The weaker students should be in smaller groups and I should make them feel safe and not nervous in class. I should try to discover what level the student is at as early as possible however; in practice I rarely implement it in my class.

Such an idea of participant 4 indicates that teacher has to use the activities in such a way that both proficient and less proficient learners can get benefits. To make them work independently, the teacher has to provide interesting exercises for the learners to work with to approach the weaker ones. However, he or she cannot maximize individual task all the times in his or her class. The more we provide students with individual work, the better it will be in a large mixedability class. His view is similar to Hess (2001) who asserts engaging students in wide range of activities and assessing them would help the teacher to identify the strengths of the students based on their involvement and performance

\section{Conclusion and Implications}

The study explores since the textbooks do not address the needs of a diverse class population; students lose their interest. Almost all the participants reported that problem of discipline, difficulty of correcting errors in written assignment, problem of addressing multiple intelligences and interests, individual attention, difficulty in managing teaching materials, lack of equal participants of learners were the major challenges of mixed ability class.

Therefore, keeping things in mind, teachers need to treat the students differently in order to maintain appropriate learning atmosphere. They should provide positive support and encouragement to the learners of different levels of proficiency with multi level tasks. To create a good atmosphere where the students feel secure, they should help them improve their own learning techniques and develop cooperation and collaboration with their peers. Using a variety of teaching methods, materials and tasks incorporating the students' own experiences, they should make mixed ability class successful. 


\section{References}

Ainslie, S. (1994). Mixed ability teaching: Meeting learners' needs. Netword 3: Teaching language to adults. London: Centre for Information on Language Teaching and Research.

Ansari, M. S. (2013). Coping with the problems of mixed ability classes: A study in the context of teaching English as SL/FL. International Journal of English: Literature, Language \& Skills. .

Baker, J. (2002). The English language teacher's handbook: How to teach large classes with few resources. New York: Continuum; London: Cassel.

Brown D.H. (2002). Strategies for success: A practical guide to learning English. New York: Longman. Brown, H.D. (2007). Teaching by principles: An interactive approach to language pedagogy. San Francisco State University: Pearson Longman.

Butterworth, D. B. (2010). Placing gifted students at-risk in mixed-ability classrooms: A sequential mixed methods analysis. Pro Quest LLC. 789 East Eisenhower Parkway, PO Box 1346, Ann Arbor, MI 48106.

Hallam, S., \& Deathe, K. (2002). Ability grouping: Year group differences in self-concept and attitudes of secondary school pupils. Westminster Studies in Education, 25(1), 7-17.

Harmer, J. (2008). How to teacher English. Longman: Cambridge University Press.

Harmer, J. (2009). The practice of English language teaching. Malaysia Longman.

Hedge, T. (2008). Teaching and learning in the language classroom. Oxford. OUP.

Hess, N. (2001). Teaching large multilevel classes. Cambridge: Cambridge University Press. Ireson I., \& Hallam, S. (2001). Ability grouping in education. London: Paul Chapman Publishing. Lightbown, P. \& Spada, N. M. (2006). How languages are learned. Oxford University Press, USA. Nusrat, D. (2017). Overcoming the challenges faced in a mixed ability classroom in Dhaka, Bangladesh. Journal of Humanities and Social Science (IOSR-JHSS) Volume 22, Issue 7, Ver. 16 (July. 2017) PP 09-14.

Richards, J. C.\& Renandya, W. A. (2010). Methodology in language teaching. Cambridge: Cambridge University Press.

Shulman, L. (1986). Those who understand: Knowledge growth in teaching. Educational Researcher, 15(2), 4-14.

Susan H. \& Judith I. (2005). Secondary school teachers' pedagogic practices when teaching mixed and structured ability classes. Research Papers In Education, Vol. 20, No. 1, pp. 3-24

Ur, P. (2005). A course in language teaching. Cambridge: Cambridge University Press.

Ur, P. (2009). A course in language teaching. Cambridge: Cambridge University Press.

Valentic, D. (2005). ELT in multi-level classes. Hupe Newsletter. 